\title{
Kovács Réka
}

\section{Az e-nyelvtanulás jelenéről és jövőjéről a slovake.eu többnyelvű, szlováknyelv-oktató weboldal tükrében}

Réka Kovács: The Present and Future of e-Language Learning as Reflected in slovake.eu, the multilingual website for the Slovak language

\begin{abstract}
Slovake.eu is described as an example for an online, multifunctional, free website teaching a small language. The website is multilingual and includes a forum, a media library, additionally facts about Slovakia and the language. Several terms have been suggested to describe online language tuition and e-learning, which is testimony to the vibrant development of the field. The most general term is e-learning, which refers to learning helped by electronic tools, especially via the Internet. Online language tuition consists of lessons designed to help achieve a specific level of competence. Although nowadays many language-learning tools are available on the Internet, according to a survey I conducted only around half of the people asked are using or have used them before. Saving money and time is given as the main reasons for e-learning. Online tuition can be successful and efficient if it is offered for free or low-priced but in good quality.
\end{abstract}

Key words: Online language tuition, e-learning, Slovak culture, language learning tools, Slovak, multilingualism

\section{ÖSSZEFOGLALÓ}

Az internet és az online tartalmak hatalmas mértékú megjelenésével különösen fontos szerepet kapott az e-nyelvtanulás.

Elöljáróban az e-tanulás, online nyelvtanfolyam és nyelvtanulási eszköz fogalmakat fogom tisztázni, majd egy kérdőív segítségével vonok le következtetéseket a 21. századi nyelvtanulási tendenciákról. Ezt követően fogom a slovake.eu honlapot vizsgálni. A slovake.eu egy olyan szlovák nyelvet tanító online felület, amely jelenleg 11 nyelven érhető el. Többek között továbbá abban tér el sok más e-nyelvtanító oldaltól, hogy az Európai Bizottság pályázatából született, ennek következtében egy kilenc partnerből álló konzorcium dolgozik azon, hogy mind a tartalom, mind a kinézet a lehető legjobb legyen. A szótáron, nyelvtani összesítókön, teszteken, fórumon, médiakönyvtáron stb. kívül érdekes tényekeket is megtudhatunk Szlovákiáról, a szlovák nyelvről és a kultúráról. A slovake.eu további e-tanító oldalak mintájául szolgálhat.

Kulcsszavak: szlovák nyelv, többnyelvűség, online nyelvtanfolyam, e-nyelvtanulás, szlovák kultúra, nyelvtanulási eszközök

\section{BEVEZETÉS}

A mai többnyelvű Európában, ahol a különböző országokban letelepedett külföldi munkavállalók száma többszörösére nőtt, s ez által a vegyes házasságok száma is megsokszorozódott, különösen fontos szerepet kapott a nyelvtanulás. Bár a nyelviskolák is népszerúek, sokan nem engedhetik meg maguknak, hogy órákra járjanak, vagy pénzügyi okokból, vagy mert nincs rá idejük. Továbbá a vegyes házasságokban előfordul az is, hogy nem kifejezetten nyelvtanulásra van szüksége a feleknek, csak ismétlésre, szinten tartásra. Az ilyen esetekben különösen hasznos lehet egy online nyelvtanfolyam. 
A témában több fogalommal is találkozhatunk, amelyek közül néhány hasonló jelentésű, néhány pedig általánosabb, gyűjtőfogalom. Ezek azonban nem összekeverendők: e-tanulás (e-nyelvtanulás, e-oktatás), „elektronikus nyelvtanfolyam" [Bicáková-Semanová 2008 - a Google erre a kifejezésre azonban nem ad találatot $\left.{ }^{4}\right]$, online nyelvtanfolyam és általában az internetes nyelvtanulási segédeszközök. A következőkben a különböző fogalmakat tisztázom és különítem el egymástól. Ezt követően egy rövid kérdőív segítségével elemzem a lehetséges tendenciákat az internetes nyelvtanfolyamok felhasználása és használhatósága szempontjából. A tanulmány harmadik felében vázolom a slovake.eu többnyelvű szlovák nyelvet oktató weboldalt egy hármas szempontrendszer alapján, az előnyök és a hátrányok mentén.

A tanulmány a teljesség igénye nélkül íródott, és a magyar viszonylatban vizsgálja az e-nyelvtanulási tendenciákat. Külföldi gyakorlatokkal és példákkal egy jövőbeni tanulmány keretein belül foglalkozom.

\section{INTERNETEN ELÉRHETŐ NYELV- TANULÁSI SEGÉDESZKÖZÖK}

A segédeszközök és egyéb fogalmak előtt érdemes definiálni az internetes/interneten elérhetö, online és elektronikus kifejezések jelentését. $\mathrm{Az}$ internetes vagy interneten elérhető anyagok olyan anyagok, amelyeket az interneten lehet fellelni, de nemcsak online módon, hanem letöltve, offline módon is használhatók. Az online eszközök vagy anyagok az interneten lelhetők fel, és online módon használhatók, tehát nem lehet őket (közvetlenül) letölteni. Az elektronika és elektronikus szavak magyarázata kissé hiányosnak túnik a Magyar értelmező kéziszótár [ÉKSz. ${ }^{2}$ ] alapján - 2003-ban minden bizonnyal még nem lehetett elterjedt a szó mai jelentése. Az elektronikus címszónál a fizikai műszó jelentését veszi először ('elektronok áramlásán alapuló'), utána az elektronikus számítógép és elektronikus zene példáknál

${ }^{4}$ Hozzáférés: 2014. 11. 05. magyarázza az elektronikus zenét ('elektromos hangszerekkel, eszközökkel komponált, előadott zene'), majd ritkább jelentésként írja az '[e]lektronikával foglalkozó <szakember>' jelentést. Az elektronika címszó második jelentése kissé közelít az általunk használthoz; '[e]lektronikus berendezés'.

Az elektronikus például szótár a Fóris-féle (Fóris 2002: 24) osztályozásban nemcsak a CDre írt, offline szótárra vonatkozik, hanem az internetes anyagokra is, tehát ez a fogalom tágabb, mint az online vagy az interneten elérhető szótár. Az elektronikus könyvtár, mint például az interneten elérhető (tehát le is tölthető) múveket tartalmazó Magyar Elektronikus Könyvtár ${ }^{5}$ szintén ezt a elméletet támasztja alá. Ma már azonban online szótárakról és elektronikus szótárakról is beszélhetünk, amelyek között a fő különbséget az online és offline hozzáférhetőség adja.

\subsection{Szótárak}

Bár a slovake.eu és a tanulmány tekintetében nem releváns eszköz a szótár - tekintve, hogy jelen dolgozat az online nyelvtanfolyamokkal foglalkozik -, mégis szólnunk kell róla röviden.

Fóris szerint az e-lexikográfia tudományterület megjelenésével igény támadt a szótár újradefiniálására [Fóris 2002: 21-24]. A szótár definíciója Fóris szerint a következőképpen szól:

„A szótár olyan egy- két- vagy többnyelvú strukturált adatbázis, amely - hordozótól függetlenül - szavak, kifejezések, fogalmak jelentését, magyarázatát, eredetét, egyszóval jellemzőit, és ezeknek adott szempont szerint, kulcsszavakkal történő osztályozását tartalmazza, egy meghatározott korpusz vizsgálata alapján" [Fóris 2002: 21]. A szótáraknak több típusa létezik, és csak egy része az, amely a nyelvtanulók számára készül.

A szótárak kategorizálásával többen foglalkoztak [Zgusta 1971, Fóris 2002, AtkinsRundell 2008]. Atkins-Rundell a következőképpen csoportosította a szótárakat:

- Nyelvek száma alapján: egynyelvű; kétnyelvű; többnyelvú.

${ }^{5}$ www.mek.hu (hozzáférés: 2014.11 .03.)$. 
Wie soll der Fachsprachenunterricht im 21. Jahrhundert sein?

- Lefedett terület alapján: általános; enciklopédikus, kulturális anyagot tartalmazó; terminológiai, szaknyelvi; a nyelv egy speciális területe (pl. frazeológiák).

- Mérete alapján: standard; kéziszótár; zsebszótár.

- Hordozó alapján: nyomtatott; elektronikus; web alapú.

- Felépítése alapján: szótól a jelentésig; szótól jelentésig, jelentéstől szóig.

- A használók nyelve alapján: ugyanazon nyelvet használók csoportja; a nyelvhasználók két speciális csoportja; a szótár nyelvét tanulók csoportja világszerte.

- A használók képessége alapján: nyelvész; írni-olvasni tudó felnőtt; iskolai tanuló; fiatal gyerek; nyelvtanuló.

- A szótár használata alapján: kódoló (idegen nyelvre fordításhoz, tanításhoz, helyes szóhasználatot elősegítő); dekódoló (a szó jelentésének megértéséhez, anyanyelvre fordításhoz) [Atkins-Rundell 2008: 24-25].

Fóris némileg hasonlóképpen kategorizál, de hozzáveszi a formátum szerinti (betûrendes vagy tematikus) csoportosítást, illetve az információ speciális biztosítása szerinti (hangosszótár, képes szótár) csoportosítást is [Fóris 2002: 24]. A 21. század technikai fejlődésével igény támadt az elektronikus szótárak kategorizálására is. Fóris a következők típusokat sorolja ide a szakirodalom alapján:

- számítógépen alkalmazott szótárak: számítógéppel olvasható szótárak (machine readable dictionary): számítógépesített szótárak (computerised dictionaries) - amelyek adatbázisként múködnek;

- „szófordító gépek” - pl. Quicktionary, Cpen;

- interneten használható szótárak - pl. MoBiDictionary;

- az új generáció a távközléssel közösen: a kommunikátor [Fóris 2004: 35].

A 2004-es csoportosítás alig tíz év alatt elavulttá vált, és az online szótárak (interaktív, akár felhasználók által szerkesztett, folyamatosan frissülő, innovatív) térhódítása megkezdődött.

Gaál Péter online szótárakról írt tanulmányában felállított szempontrendszere szerint a szótár tartalmáról szóló információk lehetnek: az online szótár fizikai leírása, azon belül technikai paraméterei, jellege (elektronikus papírszótár, valódi online), beágyazottsága (egyedülálló, szótári klaszter, szótárportál, szótári gyűjtőoldal), valamint az ára. Továbbá a szótár szerkezete, ezen belül megastruktúra (előszó, használati útmutató, segédletek, elektronikus hirdetések), makrostruktúra (keresőmotor jellege, találatok megjelenítése, közölt anyag jellege), mikrostruktúra, mezostruktúra (belső linkek, külső linkek, linkek megjelenítési formája). A szótár tartalma is lehet szempont a minősítéskor, továbbá a szótár használatáról szóló információk (szótároldal kezelhetősége, adatok megbízhatósága, információk frissítése, innovatív jellege, szakmai fontossága) [Gaál 2012: 49-50].

Az e-nyelvtanulók szempontjából fontos szempont a nyelvek számának kérdése, azaz hogy egy- vagy kétnyelvű a szótár, hogy kiknek, illetve milyen háttértudással rendelkezőknek íródott. Továbbá, hogy kódoló vagy dekódoló, speciálisan milyen szókincset tartalmaz (szintek szerinti és tematikus formátum), és hogy hangosszótár, képes szótár-e. Mint online szótár fontos szempontok ezenkívül a beágyazottsága, szerkezete (legfőképp a makrostruktúra), kezelhetősége, az adatok megbízhatósága (szerkesztők kiléte), információk frissítése. Emellett pedig nem elhanyagolható szempont az sem, hogy ingyenes-e.

\subsection{Szószedetek}

A szótáron kívül egyéb anyagok is segítik a szavak tanulását. Ilyen például a szószedet, szólista vagy glosszárium. Ezek egy leckéhez vagy témához kapcsolódó szavak listáját foglalják magukban - bár az ÉKSz. ${ }^{2}$ csak az idegen nyelvű olvasmányokból vett szavakat említi, a leckéhez tartozó szavak listája jobban visszaadja a szószedet értelmét. Állhatnak néhány szóból, kifejezésből, de akár 
többoldalnyi anyagból is a téma nagyságától és a nyelvi szinttől függően.

\subsection{Szókártyák}

A szótárakhoz hasonló, a szavak tanulását elősegítő nyelvtanulási eszközök a szókártyák, amelyekből ma már nem csak papíralapú van, de az interneten is megtalálhatjuk őket. Ezeknek számos előnye van kezdve azzal, hogy összekeverhetők, szortírozhatók, továbbá több vagy kevesebb információt tartalmazhatnak, mint a szótár. A kártyák összeválogathatók szintek szerint, tematikusan, vagy akár a ábécésorrendben.

A kártyák japánnyelv-tanuláskor használt speciális típusa a kandzsikártya, amely a kandzsik $^{6}$ megtanulását hivatott segíteni a szavak tanulása mellett. A kártya "egyik felén” szerepel a kandzsi, a „másik felén” pedig az olvasatok, beállítva pedig a jelentés is - szintek szerint.

\subsection{Nyelvtani összefoglalók}

A nyelvtani összefoglaló, ahogy nevéből is látszik, egy nyelv bizonyos nyelvtani jelenségével kapcsolatos vázlatos összefoglaló. Ezek főleg szint szerint és leckénként vannak csoportosítva. Az interneten több ilyen is található, nem feltétlenül online nyelvtanító oldalhoz kapcsolódva (jó példa erre az angol igeidők összefoglaló táblázatai vagy a prepozíciók).

Ehhez kapcsolódhatnak még az olyan jellegú segédeszközök, szoftverek, amelyek egy bizonyos nyelvtani jelenséghez adnak segítséget, mint például az olasz igeragozási oldal $^{7}$, ahol beírjuk azt az igét, amelynek a ragozására kíváncsiak vagyunk, és megkapjuk az összes igei paradigmát.

\subsection{Gyakorlófeladatok}

A gyakorlófeladat egy bizonyos probléma (kiejtés, nyelvtan, helyesírás) köré szerkesztett, különböző típusú gyakorlatok sora. Ez állhat külön, vagy lehet egy nyelvlecke része. Az

${ }^{6} \mathrm{~A}$ kínaiból átvett japán írásjegyek. Szótagot és fogalmat jelölnek.

${ }^{7}$ http://hu.bab.la/igeragozás/olasz/ (hozzáférés: 2014. 11. 03.). online gyakorlófeladatok kapcsán felmerül a kijavítás problémája, hiszen ezeknek a feladatoknak a gyakorláson kívül része az is, hogy felmérje, milyen szinten sajátítottuk el az adott anyagot, illetve $\mathrm{mi}$ az ami még gyakorlásra szorul.

A javításnak több módja van; feleletválasztós kérdéseknél viszonylag könnyú a dolog, hiszen itt a megoldható, hogy a program a végén vagy közben megadja a válasz helyességét vagy helytelenségét, és adott esetben a jó választ. Egy másik megoldás lehet akár, hogy az oldal alján találjuk a megoldásokat, vagy egy link vezet el hozzájuk. $\mathrm{Az}$ olyan feladatok esetén, mint például a levélírás, ahol a megoldás minősítése nem teljesen objektív, problémás lehet a javítás. Erre több online nyelvtanító oldal is felajánlja, hogy beküldhetjük a megoldott feladatot, amit aztán tanárok kijavítva visszaküldenek. Jó megoldások lehetnek a fórumok is. Mindenképpen szükséges bizonyos szintű interakció.

Ide sorolható még a szintfelmérő teszt is, ami (általában) egyre nehezedő feladatokat tartalmaz, és célja, hogy felmérje, a nyelvtanuló milyen szinten áll egy adott nyelvből.

\subsection{Online nyelvleckék}

A nyelvlecke már egy összetettebb, tanárt igénylő összeállítás. Egy adott szintű tananyagrész összeállítása, amely tartalmazhat szövegeket (írott, beszélt), gyakorlófeladatokat, nyelvtani összefoglalókat, szószedetet. Célja egy bizonyos tananyagrész (főleg egy nyelvtani jelenség köré szervezve) teljes szintű elsajátításának segítése.

\subsection{Online nyelvtanfolyamok, online kurzusok} A fentebb említett eszközöket átfogó, általánosabb nyelvtanulást célzó módszer a nyelvtanfolyam vagy más néven nyelvkurzus (a slovake.eu is így nevezi tanfolyamjait). A tanfolyam nyelvleckék összeállítása, amely egy nyelv meghatározott szinttől egy másik meghatározott célszintig való tanítását és elsajátítását jelenti (pl. B1-es, B2-es szintek). A nyelvleckék ezt a tanítási ívet szolgálják. Az online nyelvtanfolyamok esetében is előfordul, 
hogy óraszámban is meghatározzák, mennyi idő kell a tanfolyam befejezéséhez - bár ennek elosztása már a tanulón múlik.

\section{E-NYELVTANULÁSI TENDENCIÁK ÉS ATTITÜDÖK}

\subsection{E-nyelvtanulás}

Az e-nyelvtanulás, általánosabban e-tanulás (a keresési nyelvet magyarra állítva a Google ${ }^{8} 11$ 800 találatot ad a kifejezésre) vagy még elterjedtebb nevén e-learning (a keresési nyelvet magyarra állítva a Google 336000 találatot ad a kifejezésre) napjainkban sürün használt szavak. Az $e$ - előtag az Idegen szavak szótára [Tolcsvai Nagy 2008] szerint a következőt jelenti:

„(...) electronic (...) vmely nem elektronikus tevékenység vagy dolog elektronikus, számítógépes változata, főképp az interneten megjeleníthető v. hozzáférhető adatokkal és szolgáltatásokkal kapcsolatban (pl. e-book, email)". Ebből az látszik tehát, hogy tágabb értelemben véve minden ide tartozik, ami elektronikus, de leginkább az online használathoz köthető, tehát olyan tanulási tevékenységet jelöl, amelyhez elektronikus eszközöket használunk, főleg online eszközöket. Ezt támasztja alá Bicákovának és Semanovának (2008) a leams.com alapján megfogalmazott definíciója is: „az e-learning olyan elektronikus oktatási folyamat, amely a számítógépes hálózatot - legtöbbször a világhálót vagy valamilyen helyi hálót, mint pl. a $\operatorname{LAN}^{9}$ vagy a WAN $^{10}$ - alkalmazza az oktatásban" [BicákováSemanová 2008: 3]. M. Huba [2003, idézi Bicáková-Semanová 2008: 3] kissé másképp látja, mivel az oktatási anyag tartalmának elektronikus rendszerein való közvetítésére helyezi a hangsúlyt, ez tehát magába foglalhatja akár a tanár jelenlétét is.

\subsection{Tendenciák és attitúdök}

A munkaerőpiacon manapság elvárás, hogy az ember legalább egy, de inkább több idegen

\footnotetext{
${ }^{8}$ Megtekintés: 2014. november 3.

${ }^{9}$ Local Area Network: helyi hálózat.

${ }^{10}$ Wide Area Network: nagy kiterjedésű hálózat.

nyelvet ismerjen. A nyelvtanulás mellett azonban sok más elvárásnak is eleget kell tenni. Nem könnyú szinten tartani egy nyelvtudást mindennapi használat nélkül -, vagy akár felnőtt fejjel elkezdeni egy új nyelvet tanulni. Az e-nyelvtanulási tendenciák és attitűdök feltérképezéséhez online kérdőívet készítettem, amelynek segítségével az olyan kérdésekre kerestem a választ, mint például: igénybe vesznek-e az emberek online nyelvtanfolyamokat, ha igen, mi miatt döntöttek mellette, ha nem, akkor pedig mi lenne az, ami arra motiválná őket, hogy így tanuljanak nyelveket. A kérdőív elején feltüntettem, hogy a tanárral történő távoktatás (pl. Skype-on) és az online szótárak nem tekintendők nyelvtanulási segédeszköznek, mivel szótárat sokan használnak, így ez az adat torzította volna az eredményt. Megjegyzendő továbbá, hogy ahol releváns volt, szerepelt kitölthető "egyéb” válaszopció is. A kérdőívet 53-an töltötték ki, 43 nő (81\%) és 10 férfi (19\%). Életkorukat tekintve 18-an (34\%) 15-26 év közöttiek, 20-an (38\%) 27-36 év közöttiek, heten (13\%) 37-46 év közöttiek, hatan (11\%) 47-56 év közöttiek és ketten (4\%) 57-66 év közöttiek voltak.

Az első kérdés a következő volt: „Vesz-e vagy vett-e igénybe korábban online nyelvtanfolyamot?". A válaszok az 1 . ábrán láthatók.

Az eredményekből látszik, hogy a kitöltők körülbelül fele sosem próbált így nyelvet tanulni. A másik fele igénybe vesz vagy igénybe vett. Az egyéb válaszok közül kettő igenlő volt („,igen, de nem voltam elég kitartó", "használtam, de nem igazán tudom elmondani, hogy mennyire volt hatékony"), egy pedig nemleges („nem próbáltam még, de tervezem kipróbálni"). A megkérdezettek 13\%-ának nem vált be az online nyelvtanulás, amely így nagyjából 1/3-a (27\%) az igenlő válaszoknak.

Mivel vannak olyanok, akiknek egyszerúen nincs szükségük arra, hogy nyelvet tanuljanak, kíváncsi voltam, hogy ismernek-e olyat, aki igénybe vesz vagy vett online nyelvtanfolyamot. 


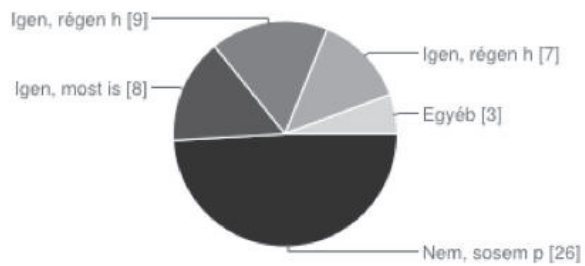

$\begin{array}{lrr}\text { Nem, sosem próbáltam. } & \mathbf{2 6} & 49 \% \\ \text { Igen, most is használom. } & \mathbf{8} & 15 \% \\ \text { Igen, régen használtam, és bevált. } & \mathbf{9} & 17 \% \\ \text { lgen, régen használtam, de nem vált be. } & \mathbf{7} & 13 \% \\ \text { Egyéb } & \mathbf{3} & 6 \%\end{array}$

1. ábra: A kérdőív első kérdésére adott válaszok

31-en nem ismernek ilyen embert, 15-en ismernek, és úgy tudják, hogy bevált neki, heten válaszolták, hogy úgy tudják, az ismerősüknek nem vált be az e-nyelvtanulás. Ez ismét nagyjából 1/3-a (32\%) az igenlő válaszoknak.

Az online nyelvtanító oldalaknak sok előnye van, fóleg a rugalmasság. Mi miatt dönthet úgy valaki, hogy online nyelvtanfolyamon tanuljon egy nyelvet. A következő kérdés tehát így szólt: „Ha használt vagy használ e-nyelvtanulási eszközöket, miért választotta ezt a módszert?”. Ez a kérdés nem volt kötelező, hiszen csak azok felé irányult, akik használtak vagy használnak ilyen eszközöket. Hatan (11\%) jókat hallottak

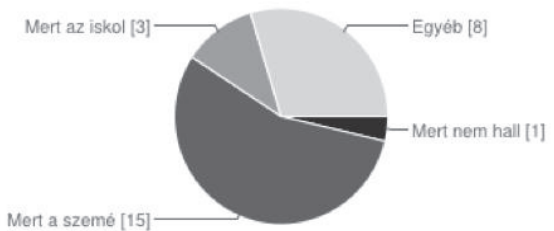

róla, kilencen (17\%) válaszolták, hogy nincs idejük tanárhoz járni, 14-en (26\%) pedig, hogy mert olcsó vagy ingyen van. Hatan adtak egyéb választ: ketten is kiemelték, hogy így időt és pénzt lehet megtakarítani, egy másik puszta kíváncsiságból próbálta ki; volt, aki interaktívnak gondolja. Ezenkívül még egy kitöltő említette a játékosságot, szórakoztatóságot, egy pedig nemleges választ adott a kérdésre (valószínúleg mert azt hitte, kötelezően válaszolnia kell).

Azt is vizsgáltam, hogy akik nem használták még e-nyelvtanulási eszközöket, miért nem tették. Ez a kérdés sem volt kötelező jellegű. $A$ válaszok a 2. ábrán láthatók.

\section{2. ábra: A kérdőív negyedik kérdésére adott válaszok}

Ahogy az ábrán látható, a kitöltők jelentős része azt válaszolta, hogy a személyes tanár-diák kapcsolatban hisz. A személyes kapcsolat kérdése nagyon megosztó. Az esetek nagy százalékában a tanulók fontosnak tartják a közvetlen kapcsolatot a tanárral, de vagy képesek feláldozni azt (a fent említett okokból), vagy a pozitív tapasztalatok megváltoztatják véleményüket. $A z$ egyéb válaszoknál szerepelt például az, hogy „lusta vagyok”.
Továbbá a hús-vér emberrel való tanulás mellett érvelt egy kitöltő: „a tanárt azért szeretem jobban, mert lehet hallani az alternatív lehetőségekről, nem csak merev válaszokat fogad el”, egy másik: „egy kompetens tanár szemtől szembe jobban el tudna magyarázni az anyagot". Emellett egyvalaki azt írta, hogy nincs eléggé informálódva az e-nyelvtanulási lehetőségekről. Egy másik kitöltő szerint jó online 
nyelvtanfolyamok nincsenek, de különböző enyelvtanulási eszközök igen.

A következő kérdés részben fedte az előzőket, de sokkal inkább a jövőbeni lehetőségekre koncentrált: „Ha a jövőben nyelvet szeretne tanulni, mi miatt választana egy online nyelvoktató oldalt?"Az alábbi válaszok születtek:

- Mert kevésbé kötött (23 válasz, 43\%).

- Mert olcsó, ingyenes (15 válasz, 25\%).

- Mert a jövőben biztosan jobb minőségú enyelvoktató oldalak lesznek a piacon (10, $19 \%)$

- Egyéb (5 válasz, 9\%).

A kötetlenség itt is magas százalékot kapott, emellett pedig a pénzmegtakarítás is fontos szempont volt. Viszonylag sokan (10\%) bíznak abban, hogy jobb minőségúek lesznek az enyelvtanító oldalak. Az egyébnél az egyik válaszadó azt írta, hogy a magántanár mellé jó kiegészítés lehet, de helyettesíteni nem tudja azt, három egyáltalán nem gondolja, hogy használna ilyen jellegú oldalt. Egy pedig a kedvező árat és rugalmasságot egyaránt fontosnak tartja.

$\mathrm{Az}$ utolsó kérdés arra vonatkozott, hogy vajon szívesebben használnának-e online nyelvtanfolyamokat, ha azok mobilalkalmazásként is elérhetők lennének. Erre a kérdésre a kitöltők 64\%-a igennel, míg $36 \%$ nemmel válaszolt.

A válaszokból levonhatunk néhány következtetést - természetesen a kérdőív nem reprezentatív, így nem 100\%-osak a következtetések. Az első: annak ellenére, hogy az internet már több mint egy évtizede teret hódított, kevesen használják ilyen jellegú dologra. A másik: a fő okok, amiért ilyen típusú eszközökhöz fordulnak az emberek, a kötetlenség és a költséghatékonyság. A harmadik: bár egy tanár, illetve a személyes kapcsolat tanár-diák között nagyon fontos (már-már nélkülözhetetlen), és sokan nem is tudnak emiatt hinni ezekben az alternatívákban, mégis többen használnák az enyelvtanulási eszközöket (akár csak kiegészítésként is), ha jobban lennének informálva a lehetőségekről, pozitiv tapasztalatokat gyűjthetnének, és minőségibb oldalak lennének a piacon.

\section{A SLOVAKE.EU NYELVOKTATÓ WEBOLDAL BEMUTATÁSA}

A slovake.eu oldalt nem szlováknyelv-tanárként és nem is nyelvtanárként, hanem bizonyos alkalmazott nyelvészeti szempontok (I. 4.2-es pont), a fent felsorolt fogalmak (I. 2-es pont) és a kérdőívből levont következtetéseim (I. 3-as pont) mentén vizsgálom.

\subsection{Az oldal és a tartalom szerkezete}

A slovake.eu egy többnyelvű, szlovák nyelvet oktató weboldal. A nyelvoktató weboldal megnevezést - az online nyelvtanfolyam helyett - az indokolja, hogy több (jelenleg két) nyelvtanfolyamot, kurzust tartalmaz. Az oldal első és egyik legfontosabb tulajdonsága, hogy jelenleg tizenegy nyelven (plusz szlovák) érhető el, amit a jobb felső sarokban már az elején át lehet állítani. A nyelvtani anyagok megtekintéséhez regisztráció szükséges. $A z$ oldal gyakorlatilag három részre oszlik: a nyelvtanulás („Tanuljon meg szlovákul!”), a kultúra („Fedezze fel Szlovákiát!”) és a fórum, amelynek témái nincsenek korlátozva („Találjon barátokat!"). Ezenkívül találhatók általános információk a projektről, a partnerekről, az oldalhasználat feltételeiről és szabályairól, tájékoztató anyagok stb. A könyvtár rész külön pontként és kissé elkülönülve szerepel, mivel ez egyrészt rengeteg anyagot tartalmaz (külső linkeket is), másrészt pedig a nyelvtanulásnak és a kultúrának is része, ahogy azt írják az oldalon is: „A könyvtárunkban a szlovák irodalmi múveken kívül megtalálható még rengeteg anekdota Szlovákiáról, szlovák közmondás, folyóirat, dal és videó, melyek közelebb hozzák Önhöz a szlovák nyelvet és kultúrát".

\subsection{Előnyök és hátrányok}

Bicáková-Semanová szerint az e-learning hatékonyságát három szempont alapján érdemes értékelni:

1. „Pedagógiai szempontból: llyenkor a nemzetközi háló és más információs technológiák alkalmazása azzal a céllal 
történik, hogy az oktatást magasabb szintre emeljük, rövidebb idő alatt nagyobb hatékonyságot éljünk el.

2. Technológiai szempontból: Ez azt mutatja, hogy hogyan valósítjuk meg a tartalom átvitelét az elektronikus médiákon keresztül.

3. Hálózati szempontból: A számítógépes hálózatok kihasználásával az adatok, információk átvitelére következtethetünk" [Bicáková-Semanová 2008: 5].

Pedagógiai szempontból a slovake.eu kapcsán elmondható, hogy a kilenc partner közül hétnek van valamilyen tapasztalata nyelvoktatási anyagok, vagy szótárak készítésében és/vagy a szlováknyelvoktatásban. A területi eloszlást illetően szlovák, horvát, francia, német, litván és magyar partner vesz részt a projektben, amely így még inkább szélesíti a nyelvoktatásban, azon belül a szlováknyelv-oktatásban szerzett tapasztalatok körét. Jelenleg A1-es és A2-es kurzusok elérhetők az oldalon, de hamarosan elkészülnek a B1-es és B2-es kurzusok is. Egy kurzus 15 leckét tartalmaz (az A1-es kurzusban van egy 0 . lecke a kiejtésről és a helyesírásról). Ezek többnyire rövid leírásokból, nyelvtani összefoglalókból, néhol videóanyagból, gyakorlófeladatokból és ellenőrző tesztből állnak. A két kurzus után a nyelvtan résznél a nyelvtani összefoglalók találhatók egymás alatt, hierarchiában, majd három különböző játék következik, amivel szórakozva, játékos módon tanulhatunk újat (fóleg szavakat és azok helyesírását).

Technológiai szempontból azt kell vizsgálnunk, hogy a tananyag átadása milyen formában, milyen technikai eszközzel és hogyan valósul meg. Minden leckének az első pontja az „Új szavak". Itt a szavakra kattintva meghallgatható a kiejtés. A szavak tanulásához még két eszköz áll rendelkezésünkre. Az egyik a bal felső sarokban lévő angol-szlovák, szlovákangol szótár, ahová közvetlenül beírhatjuk a keresett szót, emellett pedig egy pop-up szótár. A pop-up „hirdetést tartalmazó előreugró v. felugró ablak a számítógépes képernyőn, mely az éppen futó ablakot (részben) eltakarja"
(Tolcsvai Nagy 2008). Ez ma már nem feltétlenül csak hirdetéseket tartalmaz, hanem egyfajta típusa például a szótáraknak (pl. Rikaichan [Kovács 2013]). A slovake.eu oldalon a leckékben és a könyvtár anyagaiban a szavakra irányítva az kurzort egy sárga felugró ablakban jelenik meg a szó jelentése (egyelőre) angolul. A további nyelvekre is készül a szótár, amely a leggyakoribb 500-1000 szót fogja tartalmazni.

A szótanulási eszközöket tekintve bár jól kihasználja az oldal a technológia adta lehetőségeket (pop-up szótár, hanganyagok), a szavak egymás utáni felsorolása nem a legkreatívabb módszer. Sok nyelvoktató oldalon találhatunk tematikus szófelhőket, szótanítást videóval (aminek a végén már tesztelnek is), szókártyákat stb. Audio- és audiovizuális anyagoknál a szöveget megtaláljuk lejegyezve is. Emellett a segítség mellett azt is beállítható, hogy szerepeljen a fordítás vagy ne.

A gyakorlófeladatoknál (igaz-hamis, mondatból hiányzó szavak kiegészítése, kérdésválasz, mondatalkotás stb.) a válaszok beírása az oldalon történik, a helyes válasz esetében pedig a háttér bezöldül. Ezen kívül a megoldások úgy is megtekinthetők, hogy a feladat alatt lévő szövegre kattintunk („A helyes válasz megjelenítése”). Minden lecke végén leellenőrizhetjük tudásunkat egy teszt (PDFformátumban) segítségével, amelynek megoldása szintén elérhető. Nagy hiányosság az olyan feladatok gyakoroltatása, amelyek kevésbé objektívek, és ahol léteznek „alternatív lehetőségek". Ezek javítása csak úgy megoldható, ha azt a tanuló átküldi, és azt egy tanár javítja ki. Ennek finanszírozása nem minden esetben megoldott, így az önkéntes segítségben reménykedhetünk.

Hálózati szempontból a slovake.eu online módon használható, és több külső és belső linket is tartalmaz - főleg a könyvtári résznél. A slovake.eu nyelvtanító oldal a jövőben mobilalkalmazásként is elérhető lesz.

$A z$ oldal további elónyei, hogy ingyenes, többnyelvű (a nyelvek bővíthetők, jelenleg a beloruszra való fordítás folyik) és - ahogy korábban már szó volt róla - nemcsak nyelvleckéket tartalmaz, hanem számos 
információt és tényeket a szlovák nyelvvel és kultúrával kapcsolatban. Az oldal másik meglehetősen hasznos része a könyvtáron kívül a fórum. Az interakció itt tud megvalósulni tanuló-tanuló és tanuló-tanár között, a tényleges beszéd gyakorlása azonban nem igazán megoldott (csak üzenet küldhető). Bár a helyes kiejtés gyakoroltatására vannak szövegek, de az ellenőrzéssel kapcsolatban csupán ennyit mond az oldal: „[e]llenőrzésképp hallgassa meg a hanganyagot és a problémás szavakat gyakorolja be. Ne feledkezzen meg a helyes hangsúlyozásról - a szlovák nyelvben a hangsúly mindig az első szótagon van."

\section{AZ E-NYELVTANULÁS LEHETŐSÉGEI}

A HVG 2012-ben készült cikkében nem jósolnak nagy jövőt az online nyelvtanulásnak. „Az online nyelvtanulást inkább szinten tartásra, nyelvtani rendszerezésre vagy szókincsfejlesztésre ajánlják: (...) ez a forma nem nyer nagyobb teret a jövőben sem, mert alapvető számítástechnikai ismeretekre lenne szükség hozzá, ami a vidéki, idősebb vagy kevésbé iskolázott embereknél legtöbbször hiányzik" [HVG 2012]. Az idézet első fele igaznak bizonyul mindaddig, amíg a beszéd- és a szövegalkotási feladatok gyakorlása nem megoldott. Bár a jelenlegi nyelvtechnológiai fejlesztések már készen állnak ennek megoldására (beszédfelismerő, szövegelemző, gépi fordítás), ameddig nincs rá ipari igény tehát nem támogatott kellőképpen -, ez a technológiai fejlesztés még várat magára. A második állítás azonban nem teljesen igaz, ha azt nézzük, hogy a nyelvtanulás igénye nem a vidéki, idősebb, kevésbé iskolázott emberek körére jellemző, hanem olyanokra, akik ambiciózus, karrierre vágyó, aktív munkavállalók, a fiatal vagy középkorosztály tagjai, és akik legalább minimális számítástechnikai ismeretekkel rendelkeznek.

A slovake.eu többek között abban is eltér a legtöbb online nyelvtanító oldaltól, hogy nem a nagy nyelvekre (angol, német, olasz) készült, viszonylag kis nyelvet támogat, mégis 715000 használó látogatta már meg az oldalt több mint 100 országból, ez év szeptemberében pedig a 18 091. érdeklődő is regisztrált. Jó hír ez a kisebb nyelveknek, mint amilyen a magyar is.

$\mathrm{Az}$ internet már számos dologban tud nekünk segítséget nyújtani, és ezeknek a lehetőségeknek a száma csak növekedni fog. Az e-nyelvtanulás sem fog ebből kimaradni, és amint nagyobb igény támad a jobb minőségű enyelvtanító oldalakra, a technológiai támogatás is adott lesz hozzá, ehhez azonban a megfelelő informálás is szükséges, erre tehát nagyobb hangsúlyt kell fektetni.

\section{6. ÖSSZEGZÉS}

$\mathrm{Az}$ interneten számos nyelvtanulási eszköz áll rendelkezésünkre: szókártyák, nyelvtani és egyéb gyakorlófeladatok, nyelvi játékok stb. Az online nyelvtanfolyamok és online nyelvtanító oldalak vállalkoznak arra, hogy tematikusan, szintek szerint, nyelvtanárok segítségével fogják össze ezeket a lehetőségeket. Bár sok, különböző és viszonylag jó nyelvtanulási eszköz létezik, kisebb nyelvekre készített minőségi és mégis ingyenes nyelvtanfolyamokról nem tudunk igazán beszámolni. Az általam készített kérdőívből az látszik, hogy egyelőre nem élnek annyian ezzel a lehetőséggel, részint azért, mert nem hallottak róla, részint pedig mert a személyes tanár-diák kapcsolatot preferálják. $\mathrm{Az}$ is kiderült azonban, hogy kiegészítésként, vagy jó tapasztalat esetén teljes mértékben igénybe vennék az online nyelvtanfolyamot, ha minőségibb lenne, főleg idő- és pénztakarékosság végett. A slovake.eu egyik példája a kis nyelvet támogató, tanárok által szerkesztett és a technológiai lehetőségeket jól kihasználó nyelvoktató oldalaknak, ráadásul folyamatosan fejlődik, és ingyen hozzáférhető. $\mathrm{Az}$ online nyelvtanfolyamok területén technikailag lehet még fejlődni, ehhez azonban az szükséges, hogy több figyelmet kapjon ez a lehetőség, ezáltal megnőjön rá az igény és így a támogatás is.

\section{Ábrák}

1. ábra: A kérdőív első kérdésére adott válaszok. Google-diagram, saját ábra.

2. ábra: A kérdőív negyedik kérdésére adott válaszok. Google-diagram, saját ábra. 


\section{BIBLIOGRÁFIA}

[1] Atkins, B. T. S. - Michael, R. (2008): The Oxford Guide to Practical Lexicography. Oxford University Press, Oxford.

[2] Bicáková, J. - Semanová, H. (2008): A multimédiás eszközök alkalmazása az idegen nyelvek oktatásában. Alkalmazott Nyelvészeti Közlemények, III:1: 3-6.

[3] ÉKSz. ${ }^{2}$ = Pusztai Ferenc (szerk.) (2003): Magyar értelmező kéziszótár. Akadémiai Kiadó, Budapest.

[4] Fóris Á. (2002): Szótár és oktatás. Iskolakultúra-könyvek, Iskolakultúra, Pécs.

[5] Fóris Á. (2004): Gyorsító hatások a lexikográfia fejlődésében. In: Tóth, Sz. - Földes, Cs. Fóris, Á.: Lexikológiai és lexikográfiai látkép: Problémák, paradigmák, perspektívák. Fasciculi Linguistici Series Lexicographica 3, Generalia, Szeged, 35-43. p.

[6] Gaál P. (2012): Szempontrendszer online szótárak minősítéséhez. Magyar Terminológia. 5:2: 225-250. p.

[7] HVG 2012 = [sz. n.] Online nyelvoktatás. HVG 2014. május 2. 34. évf. 18. (1718.) sz. http://hvg.hu/hvgfriss/2012.18/201218_online_nyelvoktatas, letöltés dátuma: 2014. november 4.

[8] Kovács R. (2013): Rikaichan. Magyar Terminológia. 6:1: 129-132. p.

[9] Tolcsvai Nagy G. (2008): Idegen szavak szótára. Osiris Kiadó, Budapest.

[10] Zgusta, L. (1971): Manual of Lexicography. Mouton, The Hague \& Paris.

\section{FORRÁS}

[1] slovake.eu 